\title{
ORMOND EARTHQUAKE LIQUEFACTION RECONNAISSANCE REPORT
}

\author{
Steven A. Christensen'
}

\section{INTRODUCTION}

On August 10 1993, at 09h 46m UT an earthquake of magnitude (ML) 6.4 occurred near Ormond, a locality to the north west of Gisborne in the North Island of New Zealand. The epicentre of the event was $38.52^{\circ} \mathrm{S}, 177.93^{\circ} \mathrm{E}$, and had a focal depth of $48 \mathrm{~km}$ (Seismological Observatory, Institute of Geological and Nuclear Sciences Ltd.). Strong motion accelerographs at two sites on sediment in Gisborne recorded peak ground accelerations of $0.22 \mathrm{~g}$ at a distance of $20 \mathrm{~km}$ from the epicentre, while at Wairoa $(80 \mathrm{~km}$ to the $\mathrm{SW}$ of the epicentre) $0.05 \mathrm{~g}$ was recorded, at Tolaga Bay ( $30 \mathrm{~km}$ to the NE of the epicentre) $0.09 \mathrm{~g}$ was measured [Pers. Comn. J. Zhou], and strong motion lasted for 5-10 s. Intensity of MMVI was observed in the Ormond area with pockets of MMVII, the later being based in particular on the presence of liquefaction.

While there was a small amount of minor structural damage in the form of minor damage to a few bridges [see Chapman, 1993], a number of toppled chimneys, and damage to an abandoned reinforced concrete freezing works structure, the main effects of the earthquake were geotechnical ones, principally liquefaction and small slope failures [see Read \& Sritharan, 1993]. Liquefaction predominately occurred $20 \mathrm{~km}$ to the north west of Gisborne and also in a isolated site $8 \mathrm{~km}$ to the south west of Gisborne.

These cases of liquefaction appear to be particularly interesting because of the small magnitude of the earthquake and because of the large depth to the water table at some of the sites. It is likely that many of the sites were just over the limit of liquefying and will thus be of great use in calibrating empirical models. In addition, at those sites with a deep water table, liquefaction has necessarily occurred under high confining pressures, a condition for which there is a scarcity of data.

The aim of this reconnaissance study was to document the extent of liquefaction and to record the location of individual sand boils and to obtain samples of ejecta, for more detailed future studies. In addition, a number samples of ejecta were analyzed and typical particle size distributions are presented in this report.

The ejected material varies widely in its particle size,ranging from coarse silt to very fine gravel. The presence of ejected gravel adds to the interest of this earthquake.

1 Department of Civil Engineering

University of Canterbury, Christchurch.
The location of the epicentre places three of the sand boils (W1-W3) near to the limit of Kuribayashi and Tatsuoka's (1975) lower bound for the maximum distance to liquefaction from the epicentre. Evaluating their expression:

$$
\log _{10} R_{\max }=0.77 \mathrm{M}-3.6 \quad\left(\mathrm{R}_{\max } \text { in } \mathrm{km}\right)
$$

gives a maximum distance of $21 \mathrm{~km}$, while the maximum distance to the observed liquefaction was $19 \mathrm{~km}$. This observed maximum distance, combined with the relatively deep focal depth of $48 \mathrm{~km}$, adds to the value that may be gained from this earthquake in the study of liquefaction.

Particle size distributions of some of the ejecta are interesting in the fact that they are close to the limits for easily liquefiable soils as proposed by Tsuchida (1971), as can be seen in Figure 8.

This report contains documentation on the areas were liquefaction occurred, termed sites; descriptions of particularly interesting ejecta; maps locating the positions of the sand boils; graphs of particle size distributions; and detailed description of individual sand boils, given in Table A.

\section{SITE DESCRIPTIONS}

The area to the north west encompasses five individual sites, which span $7 \mathrm{~km}$ of the Waipaoa River Valley between the towns of Te Karaka to the north and Ormond to the south (see Figure 1). The valley in this area is 1 to $2 \mathrm{~km}$ wide. The area of liquefaction to the south west of Gisborne is immediately inside the stop bank of the Waipaoa River. The liquefied areas are situated on some of the most recent terraces of the flood plain. While it was not possible to locate all sand boils in the short time allocated, it is believed that the majority are recorded in this article.

The generally hilly land to the north west of Gisborne is comprised of soft mudstone rock and is generally oversteepened. The topsoil of the Waipaoa Valley is generally composed of silt and clay loam lying at various terrace levels. This valley system is aggrading rapidly with silts due to the high erosion rates in the headwaters of the Waipaoa River. Erosion has been exacerbated by land clearing during the 150 years of European settlement. Water well logs across the Waipaoa Plains indicate sequential layers of sandy gravels and silts.

At Site 1 (see Figure 2, boils 1-18), the northern most site at which liquefaction occurred, the sand boils were contained to a strip of land within $150 \mathrm{~m}$ from the edge of the surrounding 


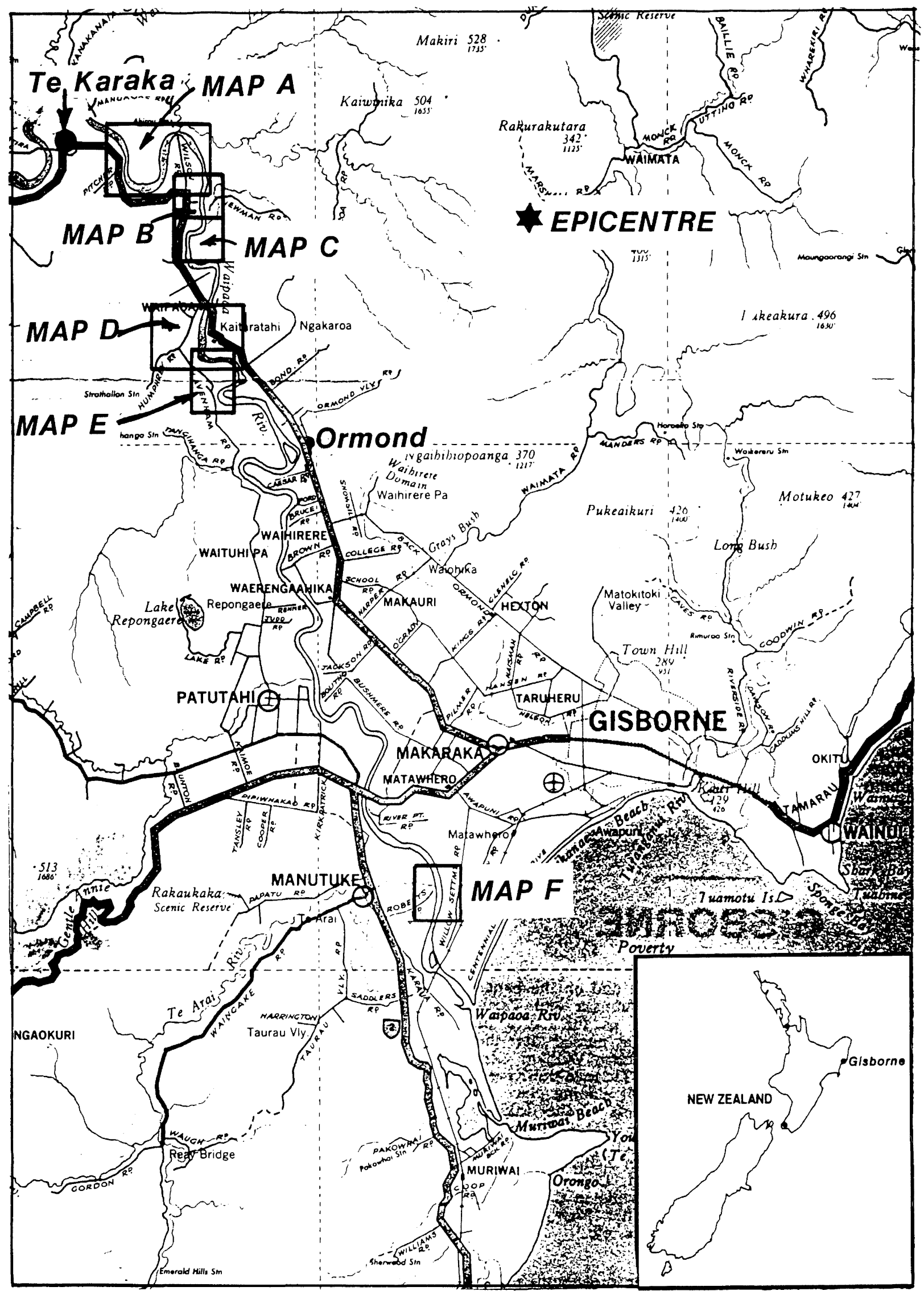

Figure 1 Ovenview Map showing areas affected by the Ormond Earthquake. 
hills in a former meander of the Waipaoa River. There was surface water lying on some parts of the ground, resulting from a combination of ejected water and rain water $(70 \mathrm{~mm}$ had fallen in the three days prior to the earthquake). A water well $300 \mathrm{~m}$ from the hills has a water level of $9 \mathrm{~m}$ below ground level. A $700 \mathrm{~mm}$ deep drain runs through the area of liquefaction with water flowing $100 \mathrm{~mm}$ deep in the bottom. Hand auguring to $3 \mathrm{~m}$ failed to locate the water table at boils $4 \& 10$, which are closer to the hills than the water well. The vents of the sand boils do not appear to be orientated in any particular direction.

Site 2 (see Figure 3, boils 19-23), lies on the true right bank of the Waipaoa River, just beside State Highway 2 . These boils are also contained in a area next to the hill side and on top of a former river meander. The sand boils lie beside a drain which is about $3 \mathrm{~m}$ below the terrace level which had approximately $200 \mathrm{~mm}$ of water flowing in it four days after the earthquake. The vents of these boils were aligned in a SE-NW direction, which is perpendicular to the nearby hills.

Site 3 (see Figures $3 \& 4$, boils 24-48), lies on the true left bank of the Waipaoa River in a former meander. The sand boils lie on the inside of this former meander, at the eastern and southern ends. A stream now flows between the hills and the terrace which is $4 \mathrm{~m}$ below the terrace level. The sand boils on the eastern edge of the former meander (boils 24-39) have in general, a E-W tendency, while the ones on the southern edge (boils $40-48$ ) have a N-S tendency. Information from the farmer suggests that this area has aggraded over $3 \mathrm{~m}$ in the previous 50 years and that the area was formerly a swamp.

Site 4 (see Figure 5, boils 49-71,75-104), is the most active in terms of the number of sand boils. This site lies on the true right bank of the Waipaoa River, near Waipaoa, with the sand boils running from the stop bank next to the river, to the base of the foot hills to the west about $1 \mathrm{~km}$ away. Many of the sand boils are aligned along the edges of former meander loops, while the remaining boils lie within the lower terraces and in some cases near the edge of the terrace on the next level. There were many small sand boils within the Waipaoa Drain, which is 2 to $3 \mathrm{~m}$ deep. The water table to the western side of the site, next to the foot hills (boils $57 \&$ 61), was established at $0.800 \mathrm{~m}$ five days after the earthquake, while halfway towards the river (boil 76), hand auguring to $5 \mathrm{~m}$ did not locate the water table. Water well logs near the stop bank in this location had water levels of $19.2 \mathrm{~m}$ and $17.7 \mathrm{~m}$ seven days after the earthquake. A 50 $\mathrm{mm}$ galvanised water pipe buried $0.5 \mathrm{~m}$ deep was broken in the area immediately to the north of the former meander where no sand boils where apparent.

Site 5 (see Figure 6, boils 72-74) is on the true right bank of the Waipaoa River. This again is a site on one of the lower terraces in a former meander loop.

Site 6 (see Figure 7, boils W1-W3), is the most southern sites, situated to the south west of Gisborne on the true right bank of the Waipaoa River near Manutuke. This site is on the edge between a former meander in the river and the current river course. As well as these three boils, many more were spotted from a light aircraft by S Read (IGNS) in the area lying between Whites Drain and Manutuke East Drain, which are shown in Figure 7.

\section{EJECTED MATERIAL}

Samples of ejecta were recovered from a large proportion of the sand boils, with a total of 110 samples being retrieved. A summary of the ejecta and description of the sand boils is given in Table A. The results for particle size determination analysis of 18 samples undertaken at the University of Canterbury are represented in Figures 8-11. Most of the sand boils are linear in shape, often with vents well aligned (see Figure 12).

The two samples of ejected gravel (boils 4 and 82 , see Figures $13 \& 14$ ), which were retrieved from the top of the boils, were most probably entrained in the ejected water from gravel layers above the layer of liquefied sand. The gravel was lying on top of uniform boils which consisted of well sorted fine grey sands. It should be noted that the gravel particle size distributions are not reliable as it is not possible to establish the matrix from which they were derived, although this does indicate the size of the larger particles.

Boil 14 (as seen in Figures 15 and 16) is unusual in that it is comprised entirely of very coarse sand and does not included any layers of finer material as is the case with most of the sand boils.

The majority of the sand boils were stratified with coarser particles on the bottom

and finer on top. This would indicate an upward progression of the liquefaction front to a more dense soil as observed by Scott and Zuckerman [1973] in the laboratory. A notable exception to the finer soil being liquefied last is seen at boil 61 (see Figure 17) where a medium brown sand overlies a thin layer of coarse grey silt.

The brown sands comprised about $35 \%$ of the ejected soils (grey soils making up the remainder), and were in general more poorly sorted than the grey, and often included pebbles.

Boils 55 and 56 contained a very small amount of ejected grey coarse silt (see Figure 18). These two boils were mainly comprised of topsoil, which was either fine particles which had been broken down by the percolating water or intact pieces of topsoil which had been lifted above the ground surface by the flowing water.

Approximately $15 \%$ of the sand boils had small traces of organics (see Figures $19 \& 20$ ) around the edges of the boils, while several kilograms were ejected from boil 30 , and deposited around the edges. The sand boils with ejected organics were mainly confined to Site 3 .

Around $30 \%$ of the sand boils at Sites 1 and 3 had traces of a yellow/brown silt which formed a foam (as reported by farmers) around the fringes of the boils, this was especially notable at boil 37 . While sieving the soils, a smell of hydrogen sulphide was apparent for many of the samples.

In addition to these more unusual features, there were a large number of more normal sand boils whose characteristics are listed in Table A. Photographs of these more typical sand boils are shown in Figures 21 - 27. 


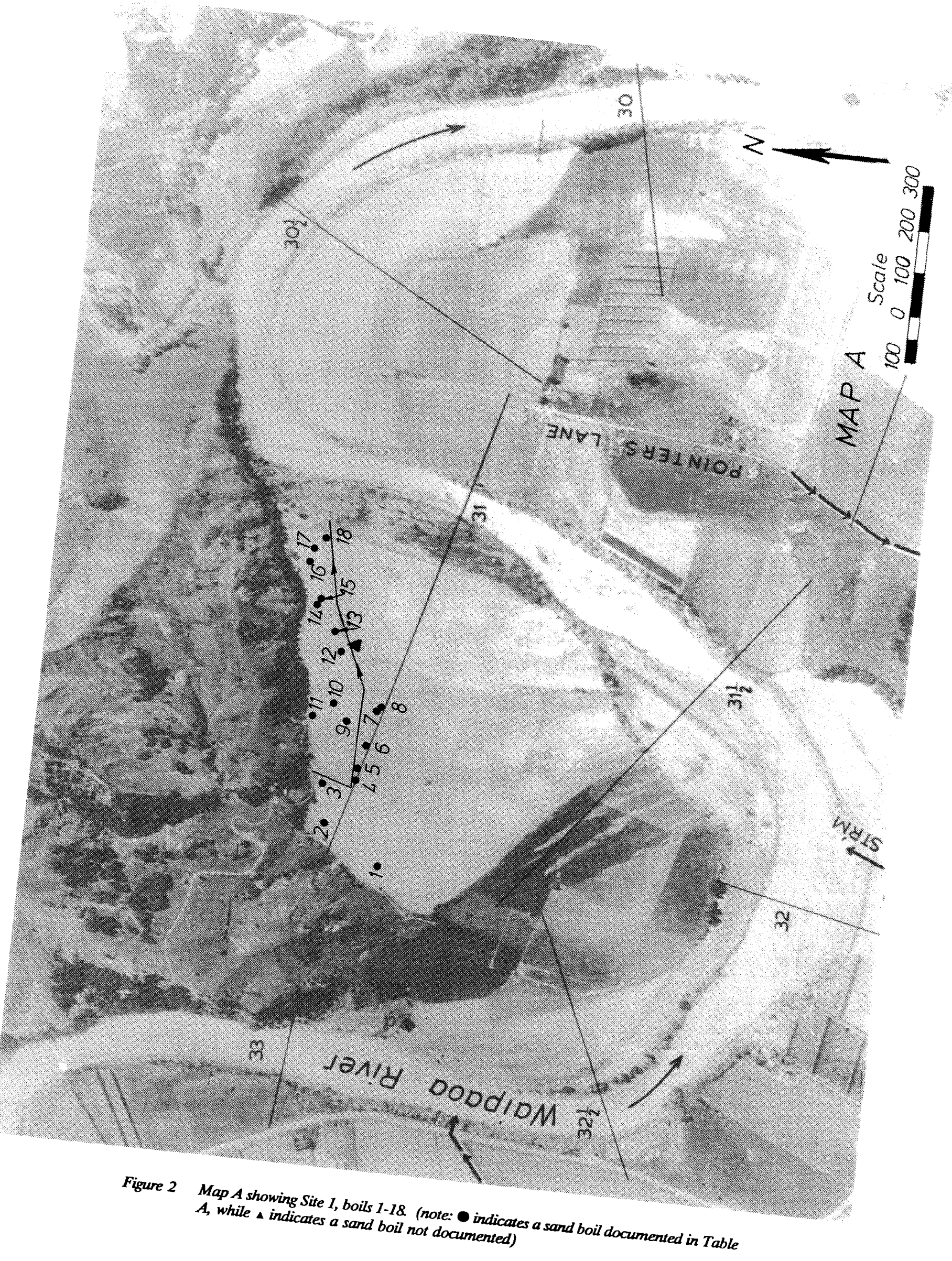




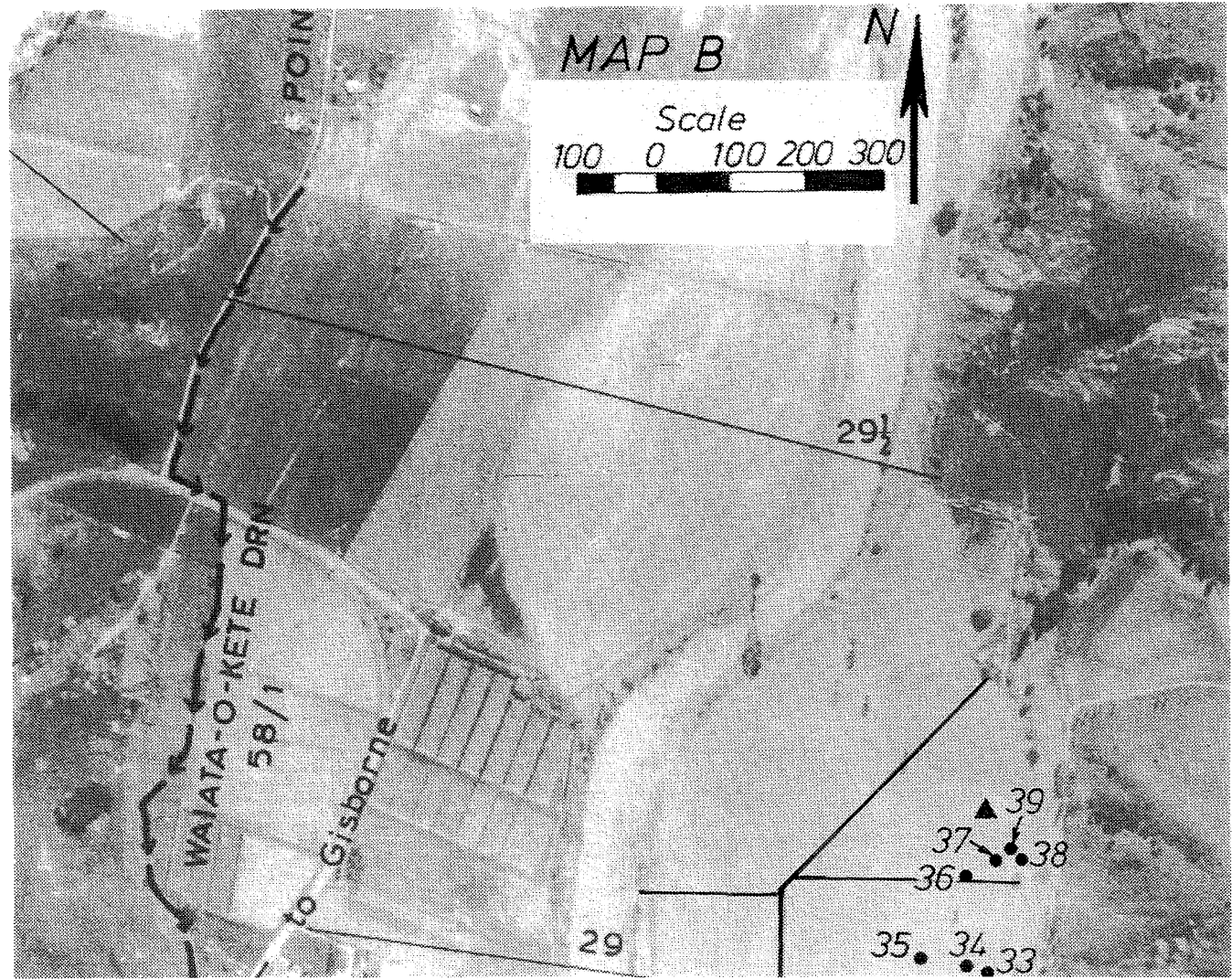

Figure 3 Map B showing Site 3, boils 33-39.

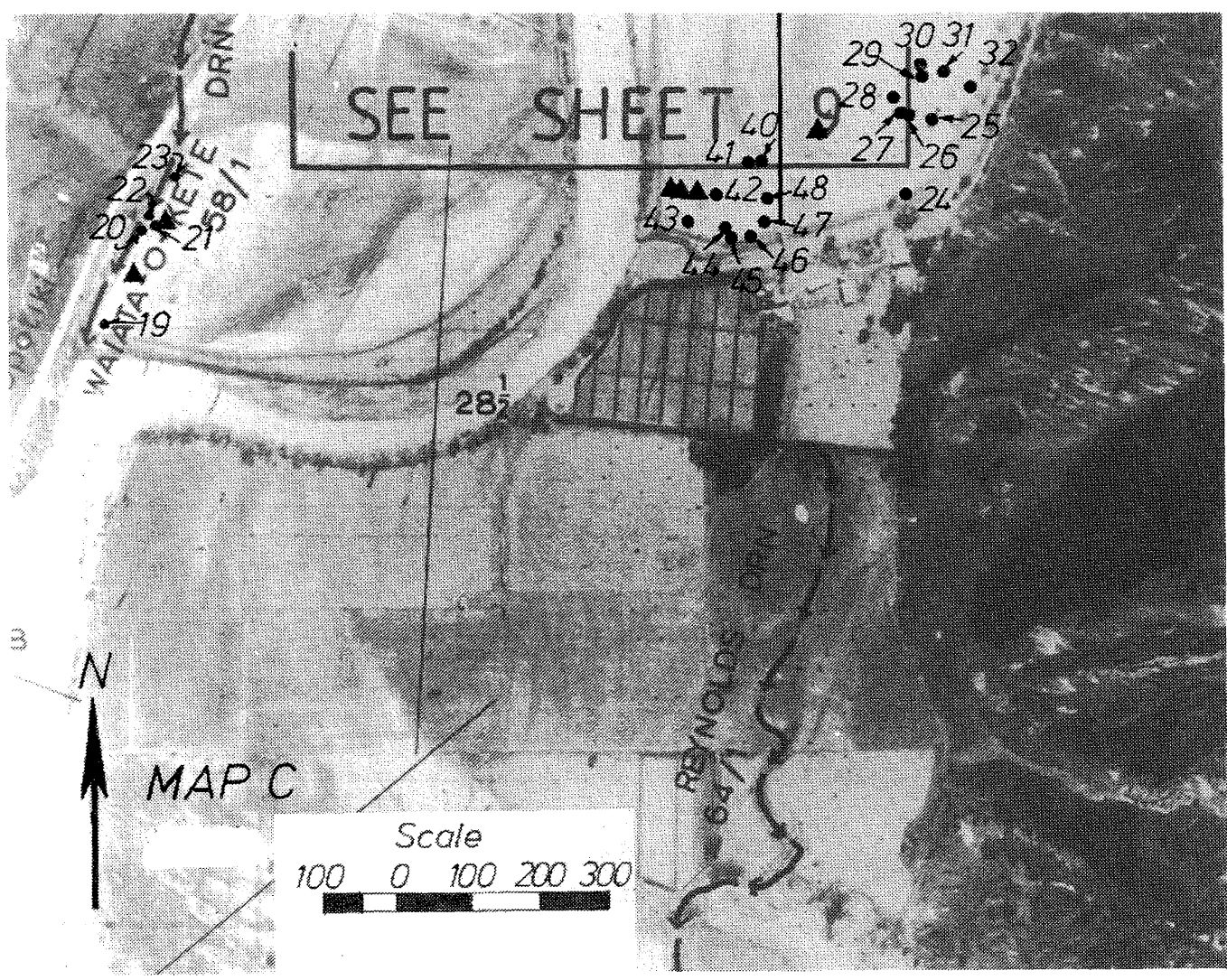

Figure 4 Map C showing Sites 2 \& 3, boils 19-32 \& 40-48. 


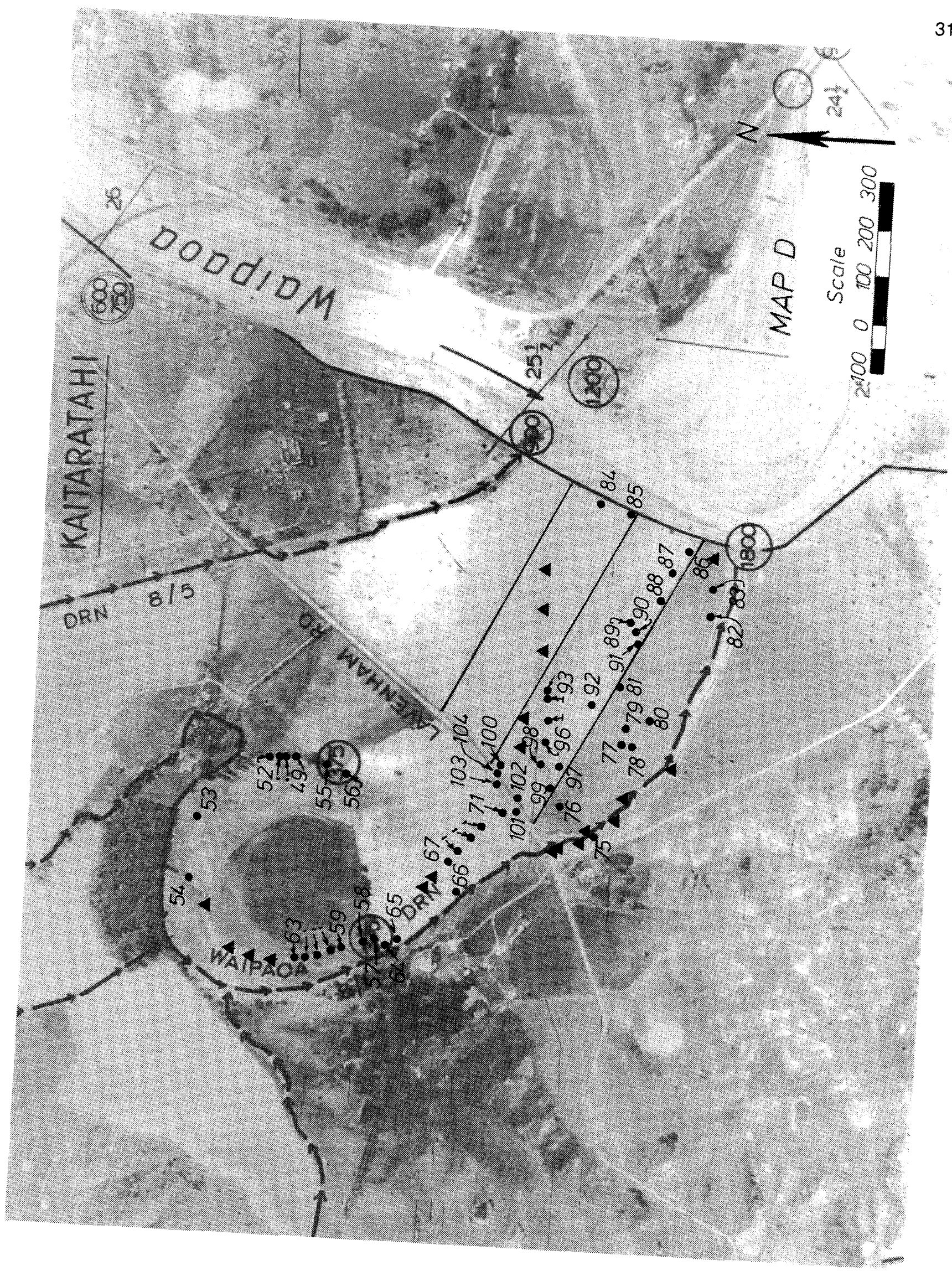

Figure 5 Map D showing Site 4, boils 49-71 \& 75-104. 


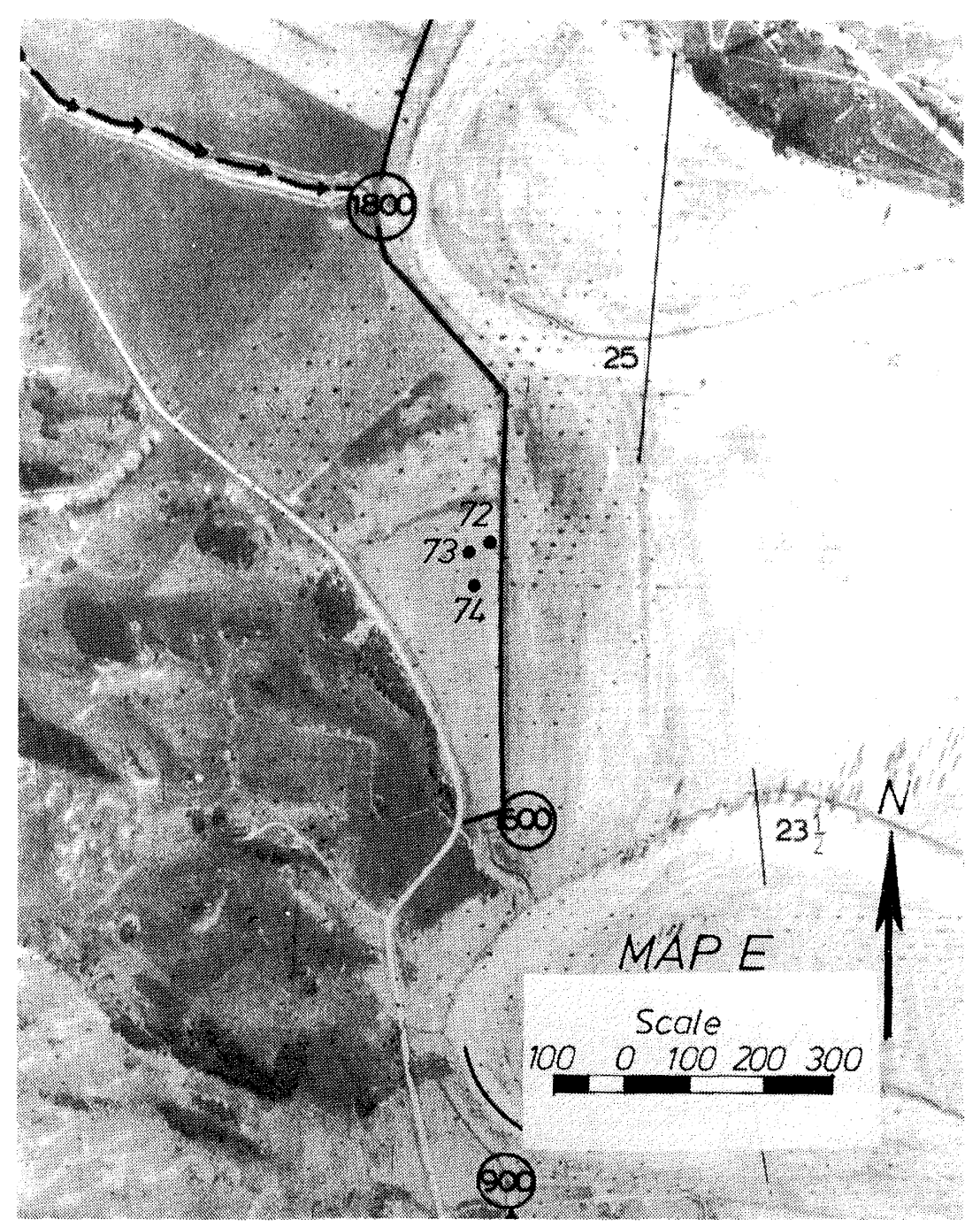

Figure 6 Map E showing Site 5, boils 72-74.

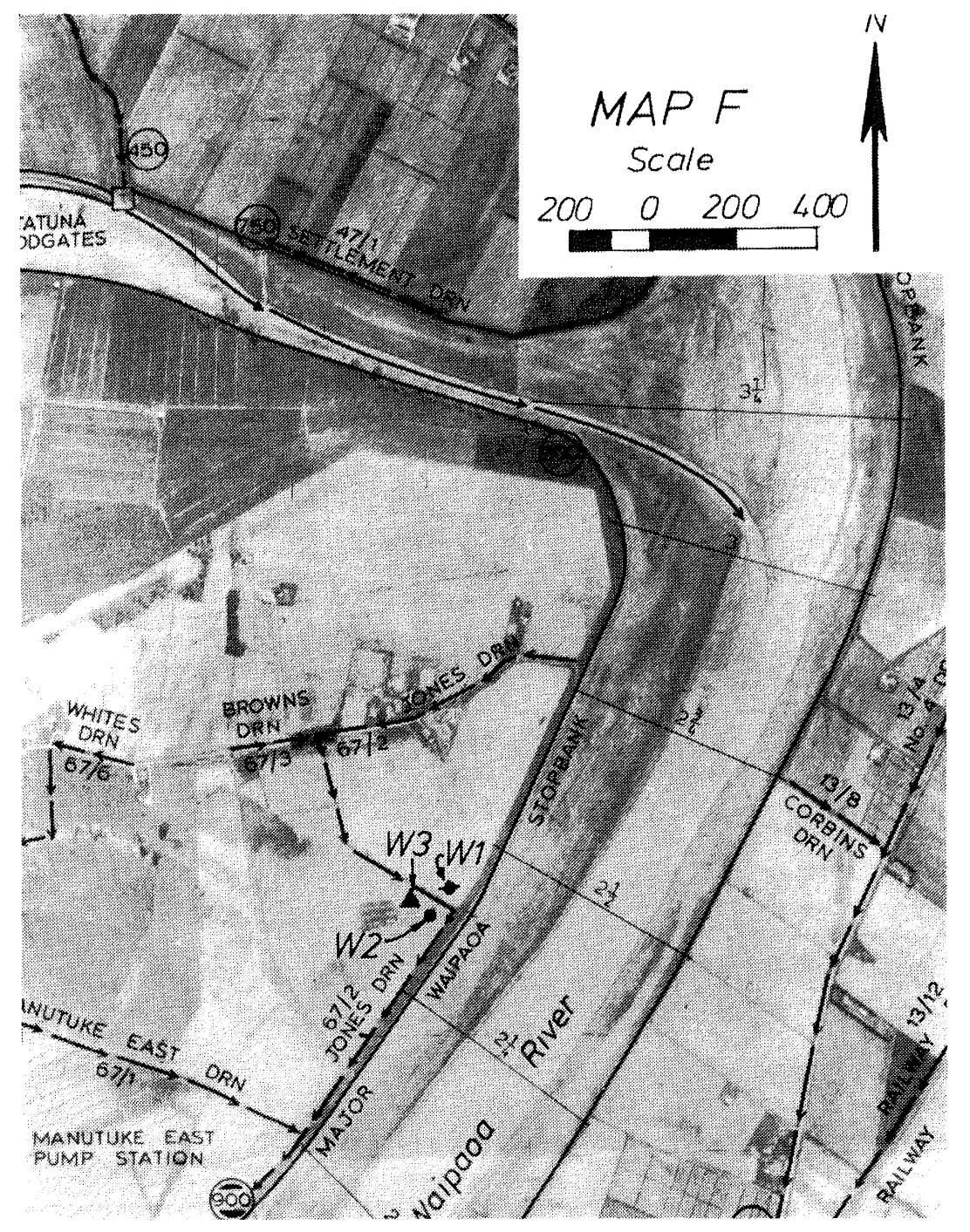

Figure 7 Map F showing Site 6, boils W1-W3 


\begin{tabular}{|c|c|c|c|}
\hline $\begin{array}{c}\text { BOIL } \\
\#\end{array}$ & MAP & $\begin{array}{l}\mathrm{BOIL} \\
\mathrm{SIZE}^{1}\end{array}$ & FIELD DESCRIPTION ${ }^{2}$ \\
\hline 1 & A & $7 \times 3$ & Fine to very fine grey sand overlying well graded medium grey sand. Depth $=0.120 \dagger \ddagger$ \\
\hline 2 & A & $12 \times 10$ & $\begin{array}{l}\text { Poorly sorted medium sand with pebbles to } 20 \mathrm{~mm} \text { lying on a } 10 \mathrm{~mm} \text { layer of well sorted fine grey } \\
\text { sand overlying a moderately well sorted medium sand. Depth }=0.120 \dagger\end{array}$ \\
\hline 3 & A & $4 \times 2$ & Well sorted very fine grey sand overlying well sorted medium to fine grey sand. Depth $=0.100 \dagger$ \\
\hline 4 & A & $24 \times 8$ & $\begin{array}{l}\text { Gravel to } 55 \mathrm{~mm} \text { in diameter lying on } 60 \mathrm{~mm} \text { of well sorted fine grey sand overlying medium grey } \\
\text { sand. Depth }=0.200 t\end{array}$ \\
\hline 5 & A & $7 \times 8$ & Well sorted very fine grey sand overlying medium grey sand. Depth $=0.060 \dagger$ \\
\hline 6 & A & $19 \times 5$ & $\begin{array}{l}\text { Poorly sorted medium grey sand with pebbles to } 10 \mathrm{~mm} \text { lying on } 10 \mathrm{~mm} \text { layer of moderately well } \\
\text { sorted medium to fine grey sand overlying a } 50 \mathrm{~mm} \text { layer of moderately sorted coarse to fine grey } \\
\text { sand. Depth }=0.075+\end{array}$ \\
\hline 7 & A & $1 \times 1$ & Similar to Boil \#6. Depth $=0.030$ \\
\hline 8 & A & $9 \times 3$ & $\begin{array}{l}5 \mathrm{~mm} \text { of grey very fine sand overlying moderately well sorted medium to fine grey sand. Depth = } \\
0.050+\end{array}$ \\
\hline 9 & A & $9 \times 1$ & Very sparse grey ejecta. Depth $=0.003$ \\
\hline 10 & A & $11 \times 10$ & $\begin{array}{l}10 \mathrm{~mm} \text { of very fine grey sand overlying well sorted fine grey sand, ejected organics near edge of boil. } \\
\text { Depth }=0.100 \dagger\end{array}$ \\
\hline 11 & A & $7 \times 1.5$ & $\begin{array}{l}5 \mathrm{~mm} \text { of grey well sorted very fine sand overlying grey moderately well sorted medium grey sand. } \\
\text { Depth }=0.100+\end{array}$ \\
\hline 12 & A & $21 \times 6$ & Moderately well sorted fine grey sand with a minor amount of very fine grey sand. Depth $=0.050 \dagger$ \\
\hline 13 & A & $2.5 \times 0.5$ & Similar to boil \# 12 . \\
\hline 14 & A & $10 \times 1.5$ & Poorly sorted very coarse grey sand. Depth $=0.050 \sharp$ \\
\hline 15 & A & $6 \times 1.5$ & $10 \mathrm{~mm}$ very fine grey sand overlying moderately well sorted medium grey sand. Depth $=0.060 \dagger$ \\
\hline 16 & A & $10 \times 15$ & $5 \mathrm{~mm}$ of very fine grey sand overlying moderately well sorted medium grey sand. Depth $=0.080 \dagger$ \\
\hline 17 & A & $2.5 \times 1$ & $\begin{array}{l}40 \mathrm{~mm} \text { of grey well sorted very fine sand to coarse silt overlying a medium grey sand. Depth }=0.060 \\
t\end{array}$ \\
\hline 18 & A & $2 \times 1$ & Similar to boil \# 17 . \\
\hline 19 & C & $45 \times 3$ & $\begin{array}{l}5 \mathrm{~mm} \text { of moderately well sorted very fine sand to coarse grey silt overlying moderately sorted medium } \\
\text { to fine grey sand, with ejected organics near the edges. Depth }=0.100 \dagger\end{array}$ \\
\hline 20 & C & $10 \times 10$ & $\begin{array}{l}100 \mathrm{~mm} \text { of well sorted very fine grey sand overlying moderately well sorted medium grey sand. Depth } \\
=0.170\end{array}$ \\
\hline 21 & C & $33 \times 2$ & $\begin{array}{l}\text { Small amount of poorly sorted coarse sand lying on } 3 \mathrm{~mm} \text { of well sorted very fine grey sand overlying } \\
\text { moderately well sorted medium grey sand. Depth }=0.170 \dagger\end{array}$ \\
\hline 22 & C & $4 \times 3$ & $\begin{array}{l}\text { Small amount of poorly sorted very coarse sand (pebbles up to } 8 \mathrm{~mm} \text { ) lying on well sorted fine grey } \\
\text { sand to a depth of } 10 \mathrm{~mm} \text { overlying a moderately well sorted coarse grey sand. Depth }=0.150 \dagger\end{array}$ \\
\hline 23 & $\mathbf{C}$ & $10 \times 3$ & Well sorted fine grey sand overlying a moderately well sorted medium grey sand. $\dagger$ \\
\hline 24 & C & $13 \times 6$ & Three equal layers of well sorted fine grey sand. Depth $=0.150 t$ \\
\hline 25 & C & $11 \times 6$ & $25 \mathrm{~mm}$ of well sorted very fine grey sand overlying medium grey sand. Depth $=0.050 \dagger$ \\
\hline 26 & C & $20 \times 3$ & Fine grey sand with ejected organics around the edges. Depth $=0.080 \dagger$ \\
\hline 27 & C & $6 \times 5$ & Similar to boil \# 26. \\
\hline 28 & C & $30 \times 10$ & $100 \mathrm{~mm}$ of well sorted very fine grey sand overlying well sorted medium brown sand. Depth $=0.140 \dagger$ \\
\hline 29 & C & $4 \times 1$ & $5 \mathrm{~mm}$ of very fine grey sand on top of well sorted medium grey sand. Depth $=0.050 t$ \\
\hline 30 & C & $16 \times 5$ & $\begin{array}{l}\text { Well sorted fine grey sand overlying poorly sorted medium brown sand (pebbles up to } 35 \mathrm{~mm} \text { ) with } \\
\text { ejected organics near edges. Depth }=0.100+\end{array}$ \\
\hline 31 & C & $11 \times 3$ & Fine grey sand overlying brown/grey medium sand. Depth $=0.200$ \\
\hline 32 & C & $3.5 \times 1.5$ & Medium grey sand. \\
\hline 33 & B & $16 \times 5$ & Very fine grey sand overlying moderately sorted medium brown/grey sand. Depth $=0.180 \dagger$ \\
\hline 34 & B & $26 \times 2$ & $\begin{array}{l}5 \mathrm{~mm} \text { of very fine grey sand overlying medium brown sand with yellow/brown foam around the edges. } \\
\text { Depth }=0.200\end{array}$ \\
\hline 35 & B & $10 \times 3$ & Moderately well sorted brown medium sand. $\dagger$ \\
\hline 36 & B & $16 \times 8$ & Poorly sorted medium sand with occasional pebbles $(5 \mathrm{~mm}) . \dagger$ \\
\hline
\end{tabular}




\begin{tabular}{|c|c|c|c|}
\hline $\begin{array}{c}\text { BOIL } \\
\#\end{array}$ & MAP & $\begin{array}{l}\mathrm{BOIL} \\
\mathrm{SIZE}^{1}\end{array}$ & FIELD DESCRIPTION ${ }^{2}$ \\
\hline 37 & B & $12 \times 8$ & Moderately sorted medium sand with yellow/brown foam around edges. $\dagger$ \\
\hline 38 & B & $12 \times 1$ & Well sorted very fine grey sand overlying moderately sorted medium grey sand. $\dagger$ \\
\hline 39 & B & $15 \times 4$ & Medium grey sand. \\
\hline 40 & $\mathrm{C}$ & $9 \times 3$ & Moderately sorted medium grey sand. + \\
\hline 41 & $\mathrm{C}$ & $12 \times 4$ & Medium grey sand. \\
\hline 42 & C & $6 \times 5$ & Well sorted fine grey sand. $¥$ \\
\hline 43 & $\mathrm{C}$ & $9 \times 5$ & Medium grey sand. \\
\hline 44 & $\mathrm{C}$ & $12 \times 4$ & Medium grey sand. \\
\hline 45 & $\mathrm{C}$ & $11 \times 3$ & Poorly sorted fine to medium brown sand (with pebbles to $15 \mathrm{~mm}$ ) $\dagger$ \\
\hline 46 & $\mathrm{C}$ & $9 \times 3$ & Poorly sorted coarse to brown medium sand (with pebbles to $8 \mathrm{~mm}$ ) $† \ddagger$ \\
\hline 47 & $\mathrm{C}$ & $20 \times 20$ & $\begin{array}{l}\text { Group of three vents: medium grey sand; fine grey sand; and } 10 \mathrm{~mm} \text { of very fine grey sand overlying } \\
50 \mathrm{~mm} \text { medium grey sand. }\end{array}$ \\
\hline 48 & $\mathrm{C}$ & $19 \times 5$ & $5 \mathrm{~mm}$ very fine grey sand overlying well sorted medium sand. Depth $=0.080 \dagger \ddagger$ \\
\hline 49 & $\mathrm{D}$ & $3 \times 1$ & Moderately well sorted medium to fine brown sand. Depth $=0.080 \dagger$ \\
\hline 50 & $\mathrm{D}$ & $6 \times 3$ & Moderately well sorted medium to fine brown sand. Depth $=0.150 t$ \\
\hline 51 & $\mathrm{D}$ & $5 \times 4$ & Moderately well sorted medium to fine brown sand. Depth $=0.160 \dagger$ \\
\hline 52 & $\mathrm{D}$ & $4 \times 1.5$ & Moderately well sorted medium brown sand. Depth $=0.080 \dagger$ \\
\hline 53 & $\mathrm{D}$ & $1 \times 0.5$ & Moderately well sorted medium brown sand. Depth $=0.040 \dagger$ \\
\hline 54 & $\mathrm{D}$ & $10 \times 8$ & Poorly sorted coarse sand. Depth $=0.005 t$ \\
\hline 55 & $\mathrm{D}$ & $1 \times 0.5$ & Ejected water, but no ejected soil. \\
\hline 56 & $\mathrm{D}$ & $1 \times 0.5$ & Ejected water, but no ejected soil. \\
\hline 57 & $\mathrm{D}$ & $12 \times 1$ & $5 \mathrm{~mm}$ of very fine grey sand overlying moderately well sorted very coarse sand. $¥$ \\
\hline 58 & $\mathrm{D}$ & $6 \times 2.5$ & $\begin{array}{l}5 \mathrm{~mm} \text { of moderately well sorted very coarse grey sand overlying well sorted very fine sand. Depth }= \\
0.050+\end{array}$ \\
\hline 59 & $\mathrm{D}$ & $7 \times 1$ & $\begin{array}{l}5 \mathrm{~mm} \text { of very fine grey sand overlying moderately well sorted medium to coarse grey sand. Depth }= \\
0.050+\end{array}$ \\
\hline 60 & $\mathrm{D}$ & $10 \times 1.5$ & $3 \mathrm{~mm}$ of very fine grey sand overlying medium sand. Depth $=0.050$ \\
\hline 61 & $\mathrm{D}$ & $12 \times 2$ & $\begin{array}{l}5 \mathrm{~mm} \text { of fine grey sand under moderately well sorted coarse brown sand (pebbles to } 15 \mathrm{~mm} \text { ). Depth } \\
=0.075 t\end{array}$ \\
\hline 62 & $\mathrm{D}$ & $3 \times 1$ & Coarse brown sand. \\
\hline 63 & D & $5 \times 1$ & Well sorted very fine brown sand. Depth $=0.050+$ \\
\hline 64 & $\mathrm{D}$ & $5 \times 5$ & Well sorted very fine grey sand. Depth $=0.030 t \ddagger$ \\
\hline 65 & $\mathrm{D}$ & $15 \times 3$ & Well sorted very fine grey sand. $\dagger$ \\
\hline 66 & $\mathrm{D}$ & $3 \times 3$ & Very small amount of grey ejecta. \\
\hline 67 & $\bar{D}$ & $17 \times 3$ & $\begin{array}{l}30 \% \text { of boil covered with very fine grey sand overlying a well sorted medium brown sand. Depth }= \\
0.150+\end{array}$ \\
\hline 68 & $\mathrm{D}$ & $16 \times 3$ & $\begin{array}{l}40 \% \text { of boil covered with very fine grey sand overlying a well sorted medium brown sand. Depth }= \\
0.150+\ddagger\end{array}$ \\
\hline 69 & $\mathrm{D}$ & $13 \times 8$ & $\begin{array}{l}80 \% \text { of boil covered with very fine grey sand overlying a moderately well sorted medium brown sand. } \\
\text { Depth }=0.150 \dagger\end{array}$ \\
\hline 70 & D & $14 \times 3$ & $\begin{array}{l}50 \% \text { coverage of boil with } 5 \mathrm{~mm} \text { of very fine grey sand overlying moderately well sorted medium } \\
\text { brown sand. Depth }=0.200 \dagger\end{array}$ \\
\hline 71 & $\mathrm{D}$ & $16 \times 5$ & $\begin{array}{l}90 \% \text { coverage of boil with very fine grey sand overlying moderately well sorted medium brown sand. } \\
\text { Depth }=0.150+\end{array}$ \\
\hline 72 & $\mathrm{E}$ & $14 \times 4$ & $\begin{array}{l}\text { Traces of very fine grey sand overlying moderately well sorted medium to fine grey sand. Depth }= \\
0.100 \dagger\end{array}$ \\
\hline 73 & $\mathrm{E}$ & $27 \times 8$ & Well sorted very fine grey sand overlying well sorted fine grey sand. Depth $=0.150+\ddagger$ \\
\hline 74 & $\mathrm{E}$ & $8 \times 3$ & Well sorted fine to very fine grey sand. Depth $=0.075 t$ \\
\hline 75 & $\mathrm{D}$ & $4 \times 3$ & Moderately well sorted medium grey sand with minor very fine sand. Depth $=0.050 \dagger$ \\
\hline
\end{tabular}




\begin{tabular}{|c|c|c|c|}
\hline $\begin{array}{c}\text { BOIL } \\
\#\end{array}$ & MAP & $\begin{array}{l}\text { BOIL } \\
\text { SIZE }^{1}\end{array}$ & FIELD DESCRIPTION ${ }^{2}$ \\
\hline 76 & D & $32 \times 10$ & Well sorted medium grey/brown sand. Depth $=0.080+$ \\
\hline$\pi$ & D & $19 \times 3$ & Fine grey sand with minor very fine grey sand on top. Depth $=0.100$ \\
\hline 78 & D & $36 \times 8$ & Moderately well sorted medium to fine grey sand with minor very fine sand on top. Depth $=0.150 \dagger$ \\
\hline 79 & D & $4 \times 2$ & Moderately well sorted medium to fine grey sand with minor very fine sand on top. Depth $=0.080 \dagger$ \\
\hline 80 & D & $23 \times 9$ & Well sorted fine grey sand with minor very fine grey sand on top. Depth $=0.120+$ \\
\hline 81 & D & $18 \times 9$ & Well sorted fine grey sand with $5 \mathrm{~mm}$ of very fine grey sand on top. Depth $=0.100 \dagger$ \\
\hline 82 & D & $21 \times 13$ & Well sorted fine grey sand with minor very fine sand and pebbles on top. Depth $=0.150+ \pm$ \\
\hline 83 & D & $15 \times 4$ & Well sorted fine grey sand with minor very fine sand and pebbles on top. Depth $=0.150 \dagger$ \\
\hline 84 & D & $10 \times 2$ & $3 \mathrm{~mm}$ of very fine grey sand covering $50 \%$ of boil overlying medium grey sand. Depth $=0.300$ \\
\hline 85 & D & $10 \times 8$ & $3 \mathrm{~mm}$ of very fine grey sand covering $80 \%$ of boil overlying medium grey sand. Depth $=0.300$ \\
\hline 86 & D & $7 \times 3$ & $\begin{array}{l}3 \mathrm{~mm} \text { very fine grey sand overlying poorly sorted very coarse sand (pebbles to } 10 \mathrm{~mm} \text { ). Depth }= \\
0.050 \mathrm{t}\end{array}$ \\
\hline 87 & D & $10 \times 2$ & Very fine grey sand overlying moderately sorted medium sand. Depth $=0.090 \dagger$ \\
\hline 88 & D & $3 \times 3$ & $1 \mathrm{~mm}$ of very fine grey sand overlying moderately sorted medium sand. Depth $=0.080 \dagger$ \\
\hline 89 & $\mathrm{D}$ & $13 \times 2.5$ & Well sorted medium grey sand. $\dagger$ \\
\hline 90 & D & $29 \times 2.5$ & $\begin{array}{l}2 \mathrm{~mm} \text { very fine grey sand with a few pebbles overlying well sorted medium brown sand. Depth }= \\
0.150+\end{array}$ \\
\hline 91 & D & $36 \times 13$ & $\begin{array}{l}\text { 95\% coverage of a moderately well sorted fine grey sand overlying well sorted medium brown sand. } \\
\text { Depth }=0.150+\end{array}$ \\
\hline 92 & D & $8 \times 2$ & $\begin{array}{l}\text { Very fine grey sand }(10 \mathrm{~mm}) \text { overlies a medium brown sand }(20 \mathrm{~mm}) \text { which overlies a coarse to } \\
\text { medium brown sand }(30 \mathrm{~mm}) \text {. }\end{array}$ \\
\hline 93 & $\mathrm{D}$ & $20 \times 3$ & Very fine grey sand overlying medium brown sand. Depth $=0.150$ \\
\hline 94 & D & $4 \times 1$ & Minor very fine grey sand overlying medium brown sand. Depth $=0.100$ \\
\hline 95 & D & $23 \times 5$ & $98 \%$ coverage of very fine grey sand overlying medium brown sand. Depth $=0.150$ \\
\hline 96 & $\mathrm{D}$ & $4 \times 1$ & $1 \mathrm{~mm}$ very fine grey sand overlying grey/brown medium sand. Depth $=0.050$ \\
\hline 97 & D & $12 \times 5$ & $\begin{array}{l}15 \mathrm{~mm} \text { of well sorted fine to very fine grey sand overlying well sorted fine brown sand. Depth }= \\
0.120+\end{array}$ \\
\hline 98 & D & $28 \times 4$ & $\begin{array}{l}3 \mathrm{~mm} \text { of fine brown sand overlying moderately well sorted medium to fine brown sand. Depth }= \\
0.100+\end{array}$ \\
\hline 99 & D & $15 \times 2$ & Brown/grey medium to fine sand. Depth $=0.120$ \\
\hline 100 & D & $4 \times 2$ & Very fine grey sand overlying medium grey sand. Depth $=0.080$ \\
\hline 101 & D & $19 \times 1$ & Moderately sorted medium grey sand. Depth $=0.150 \dagger$ \\
\hline 102 & D & $12 \times 1$ & Moderately sorted medium to fine brown/grey sand. Depth $=0.100 t$ \\
\hline 103 & D & $42 \times 1$ & $\begin{array}{l}\text { Moderately sorted medium brown/grey sand with very fine grey sand towards the ends. Depth = } \\
0.100+\end{array}$ \\
\hline 104 & D & $13 \times 2$ & $\begin{array}{l}\text { Moderately well sorted medium to fine grey sand at the southern end and moderately well sorted fine } \\
\text { grey sand at the northern end. Depth }=0.100+\end{array}$ \\
\hline W1 & $\mathbf{F}$ & $12 \mathrm{~m}$ long & Grey well sorted fine sand. $t$ \\
\hline W2 & F & $11 \mathrm{~m}$ long & Grey moderately well sorted medium to fine sand. $t$ \\
\hline W3 & $\mathbf{F}$ & $10 \mathrm{~m}$ long & Grey moderately well sorted fine sand. $\dagger$ \\
\hline
\end{tabular}

NOTES: 1) All sizes are given in metres unless otherwise stated and are maximum dimensions.

2) Hand held lens used to describe soils, sizes are as follows: very coarse sand 1-2 mm; coarse sand 0.5-1 mm; medium sand 0.25-0.5 $\mathrm{mm}$; fine sand $0.125-0.25 \mathrm{~mm}$; very fine sand $0.063-0.125 \mathrm{~mm}$; and coarse silt $0.004-0.063 \mathrm{~mm}$

$\dagger$ Soil sample(s) retrieved from this boil.

¥ Particle size distribution given in this article. 


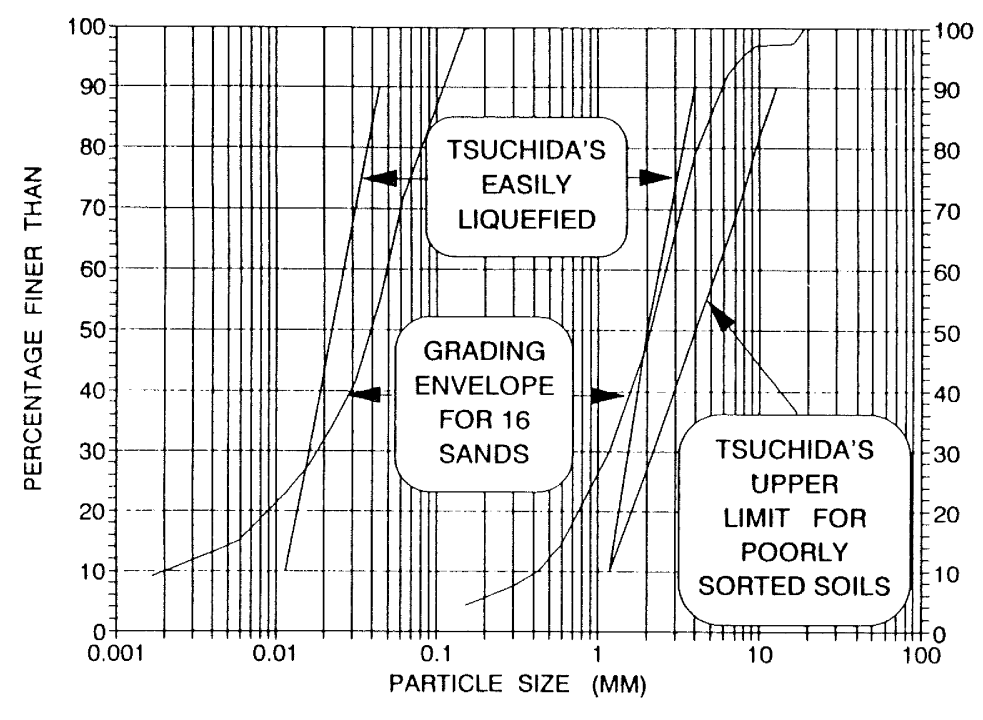

Figure $8 \quad P S D$ of the Ormond samples compared with Tsuchida's boundaries.

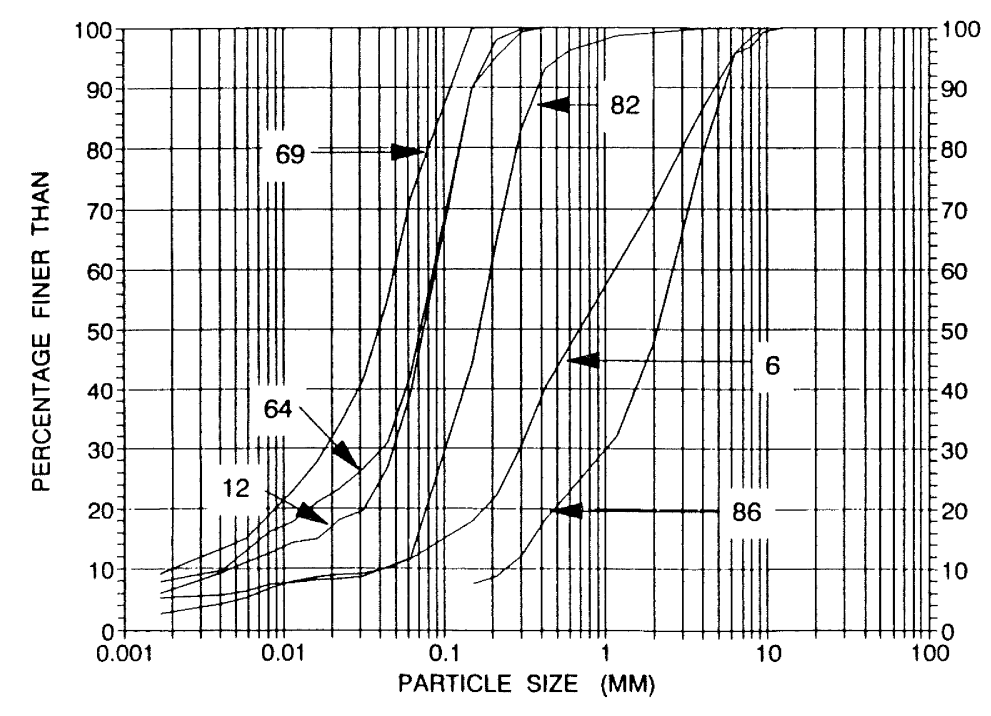

Figure 10 PSD for samples from boils 6, 12, 64, 69, 82 and 86

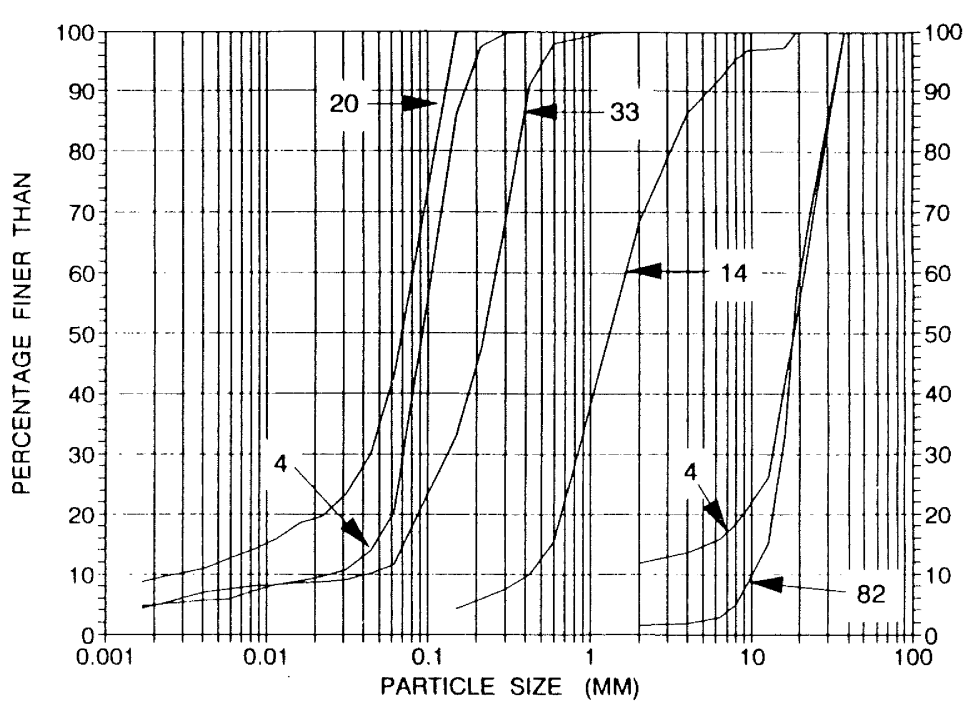

Figure 9 PSD for samples from boils 4(x2), 14, 20, 33 and 82

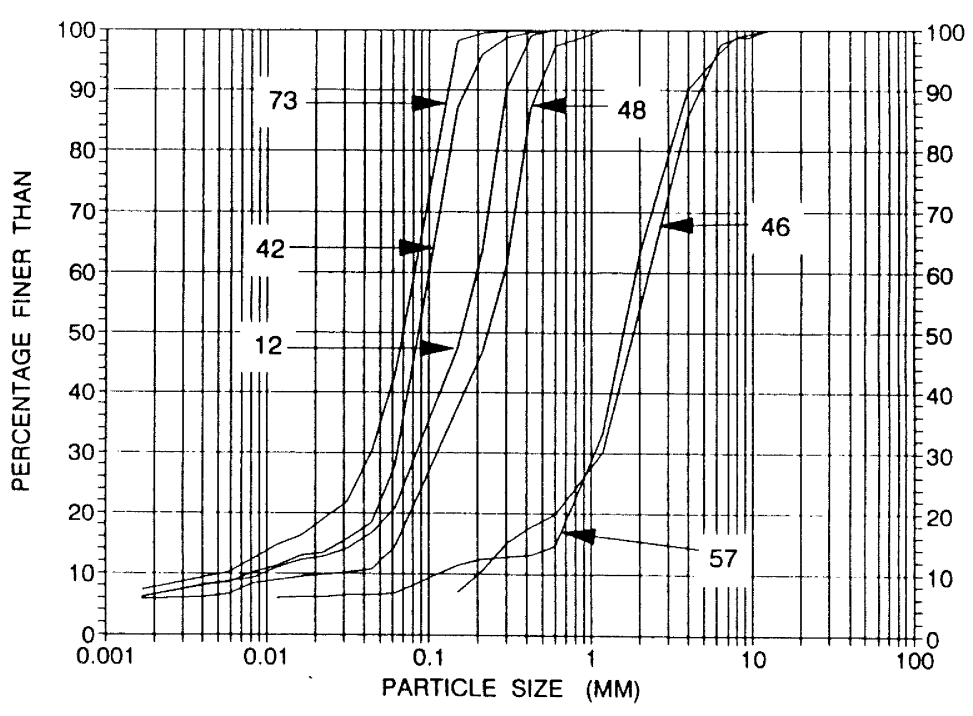

Figure 11 PSD for samples from boils 12, 42, 46, 48, 57 and 73. 


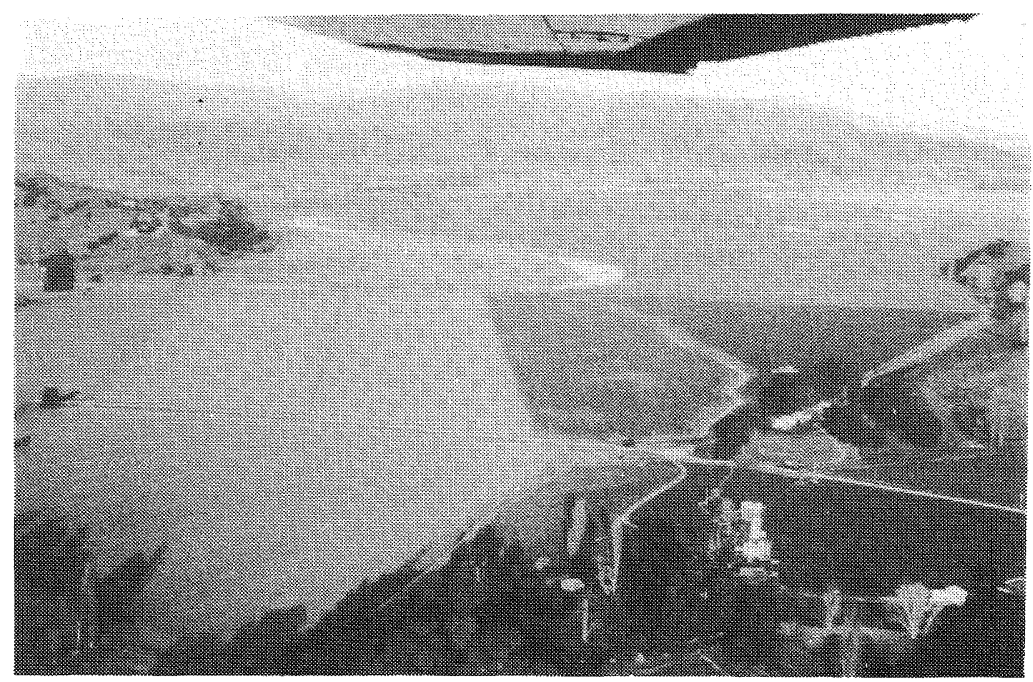

Figure 12 Overview of Site 4 showing line of boils 67-71 in foreground.

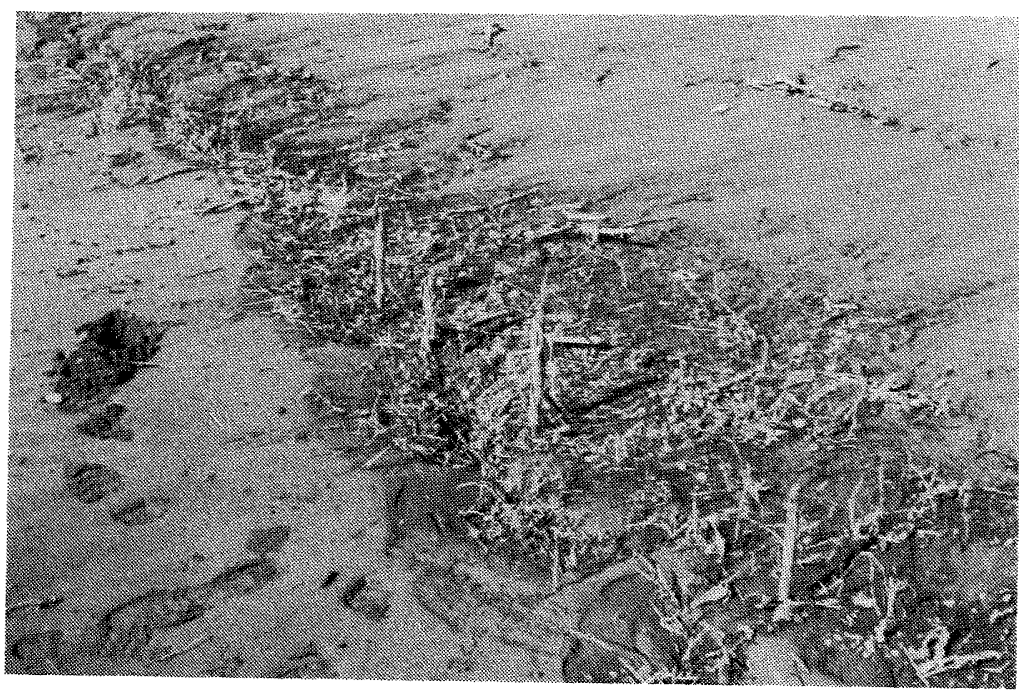

Figure 13 Boil \#4 in cultivated maze paddock showing extent of gravel bying on top of fine grey sand ejecta.

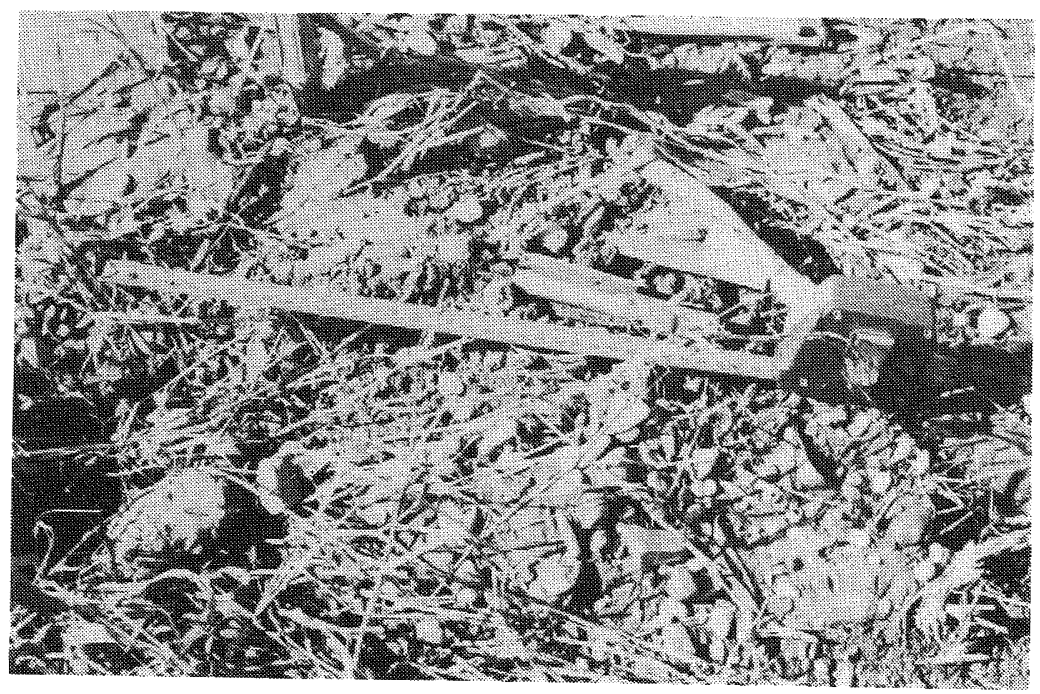

Figure 14 Claseup of gravel on top of boil \#4. 


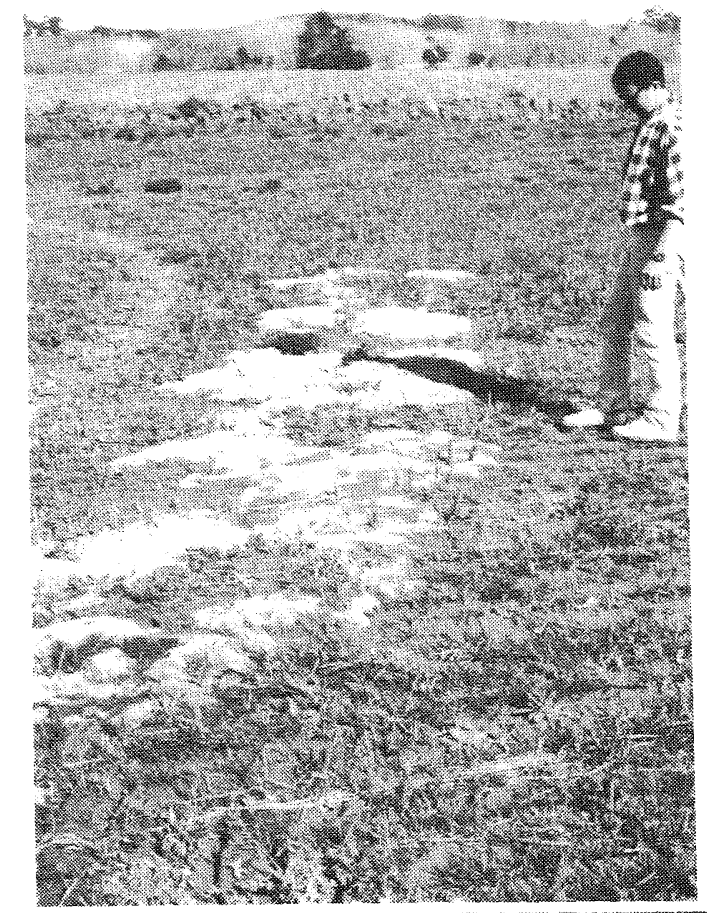

Figure 15 Looking south at boil \#14 consisting of a poorty sorted fine gravel.

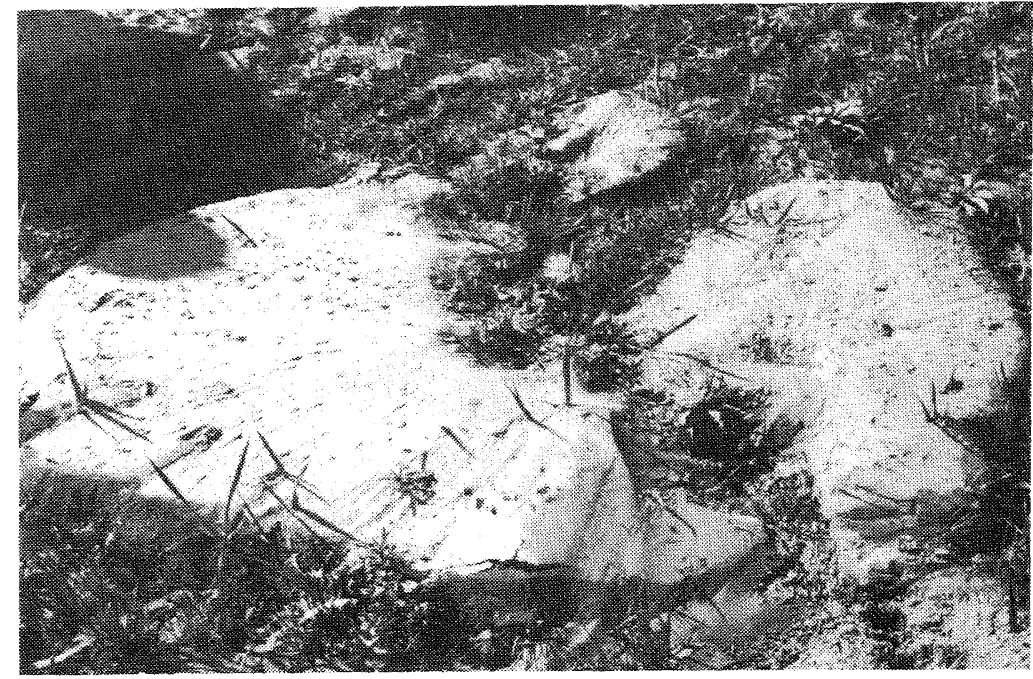

Figure 16 Closeup of boil \#14 which is a poorty sorted fine gravel.

Figure 17 Closeup of boil \#61 showing coarse grey silt under medium brown sand.

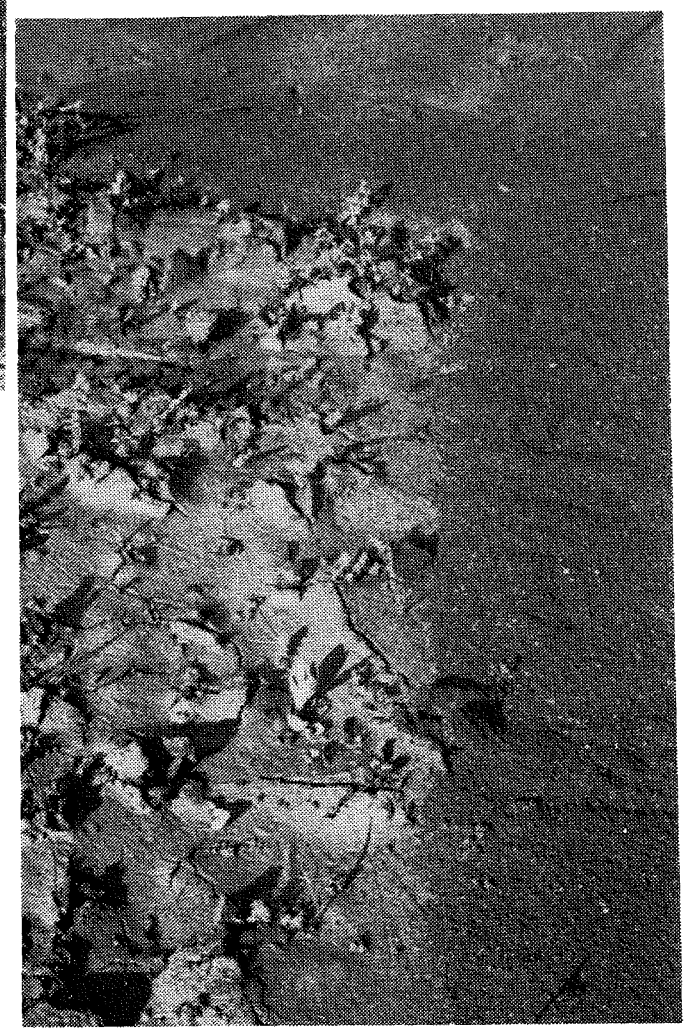




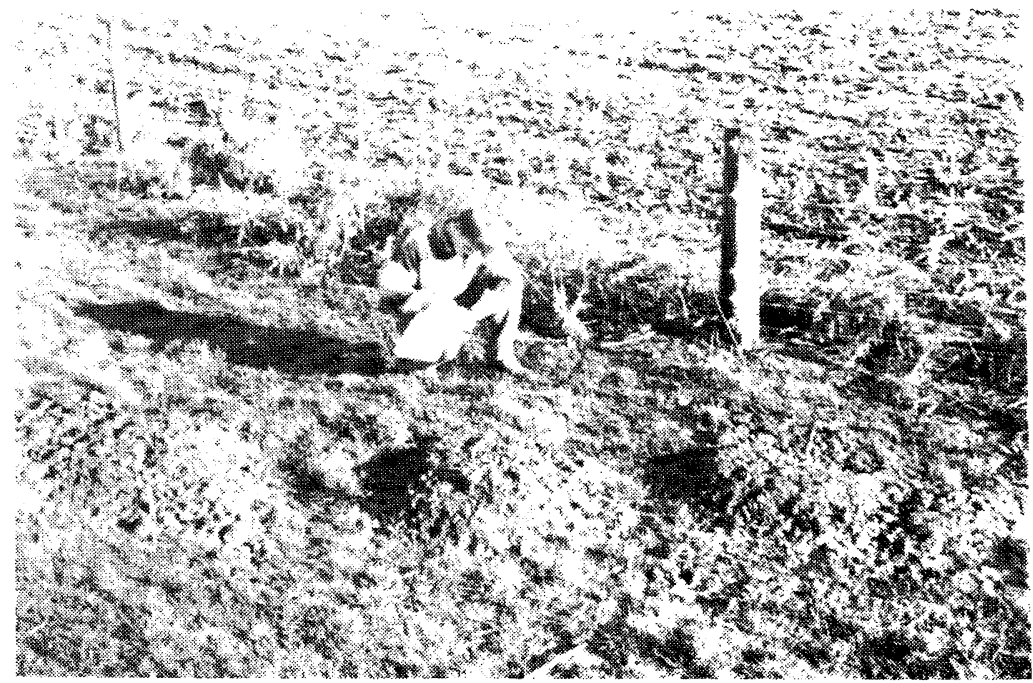

Figure 18 Area of ejected water, producing mounds of topsoil (boil \#56).

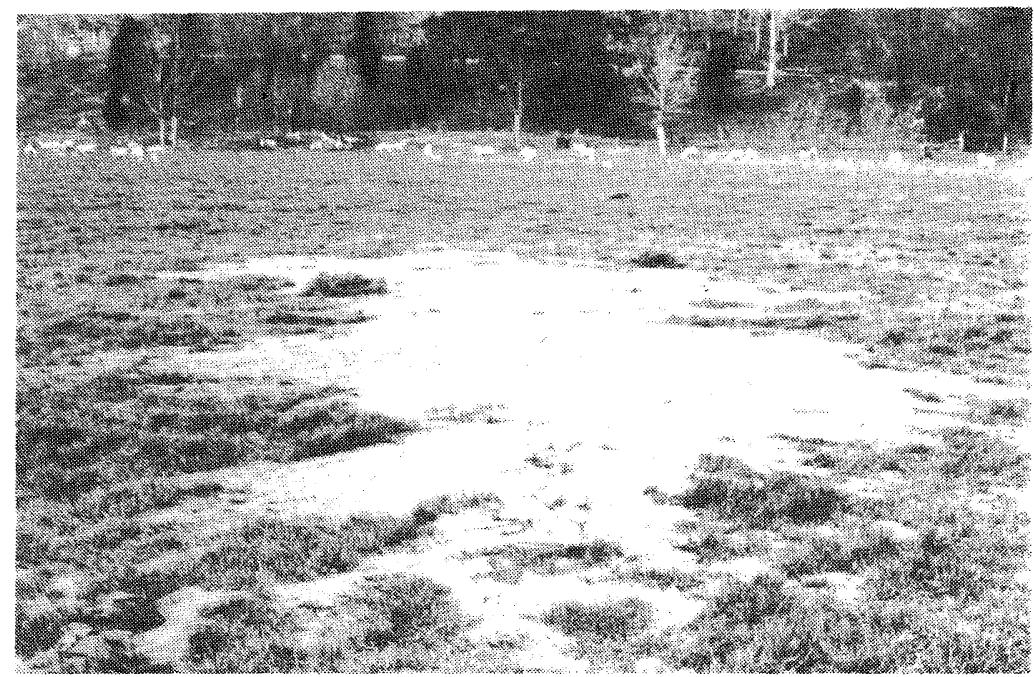

Figure 19 Typical boil (\#30) of medium sand, with thin layer of fine sand on top, looking towards the east.

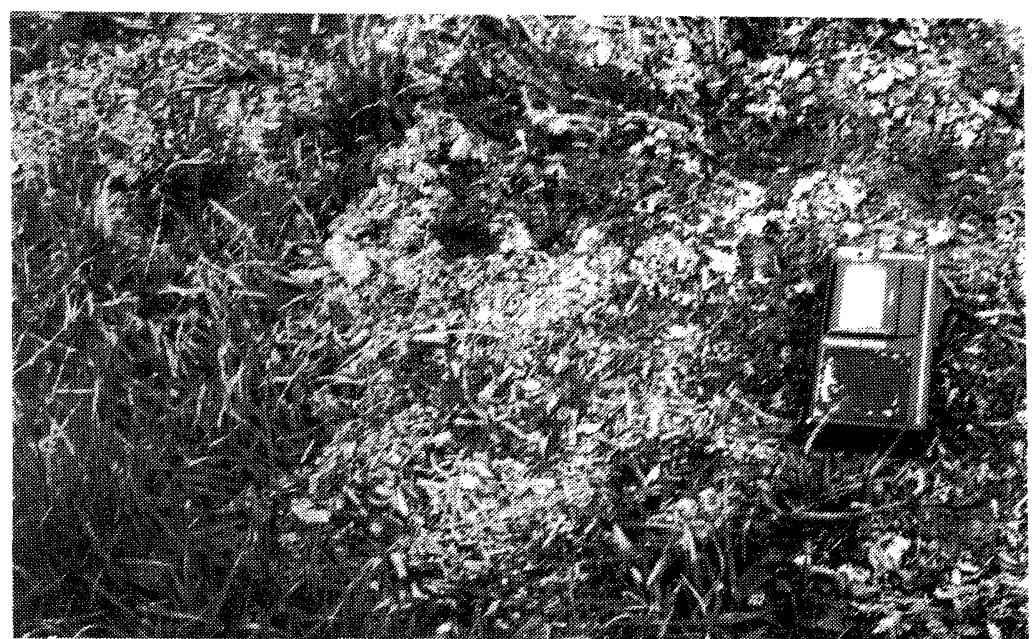

Figure 20 Closeup of central left lobe of boil \#30 showing ejected organics. 


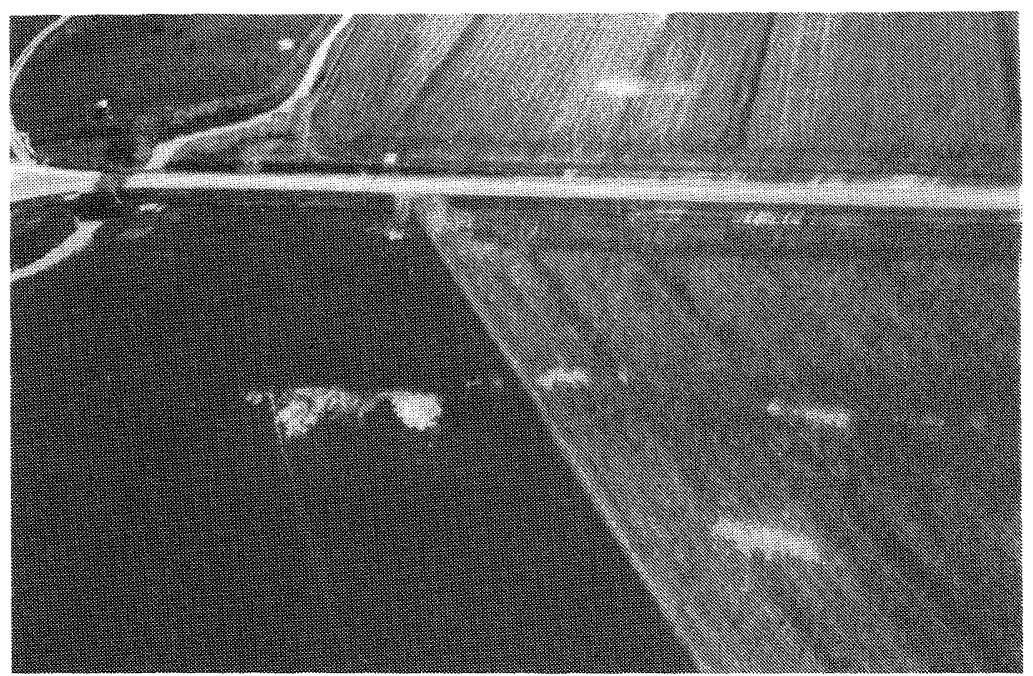

Figure 21 Aerial view of Site 4 looking west, showing typical boils.

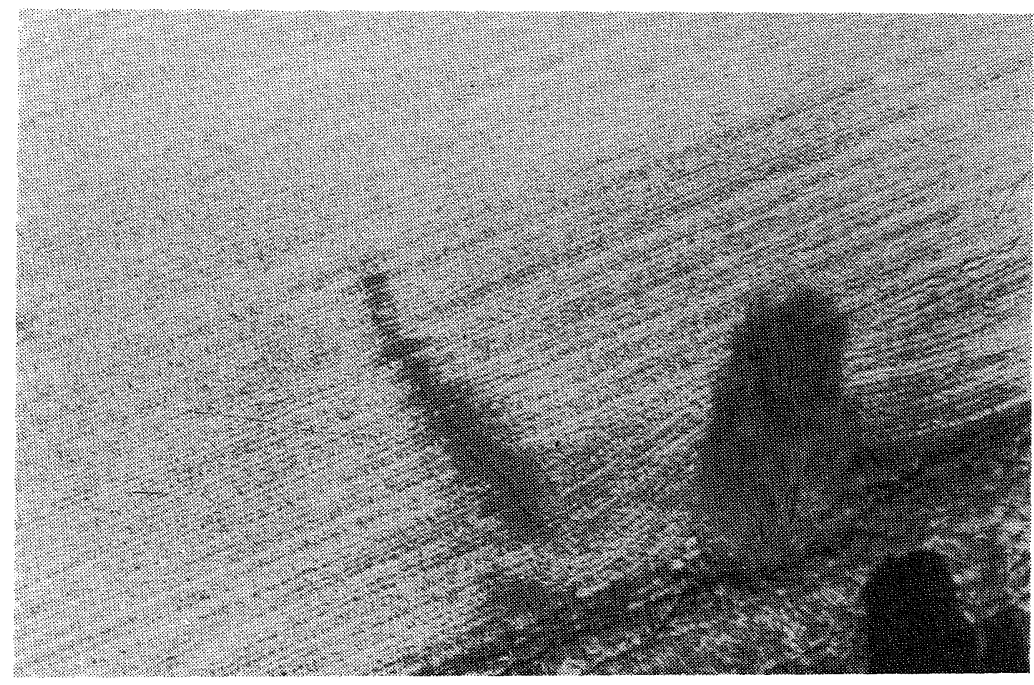

Figure 22 Aerial view of Site 2 looking in $S E$ direction showing a long linear boil (\#21).

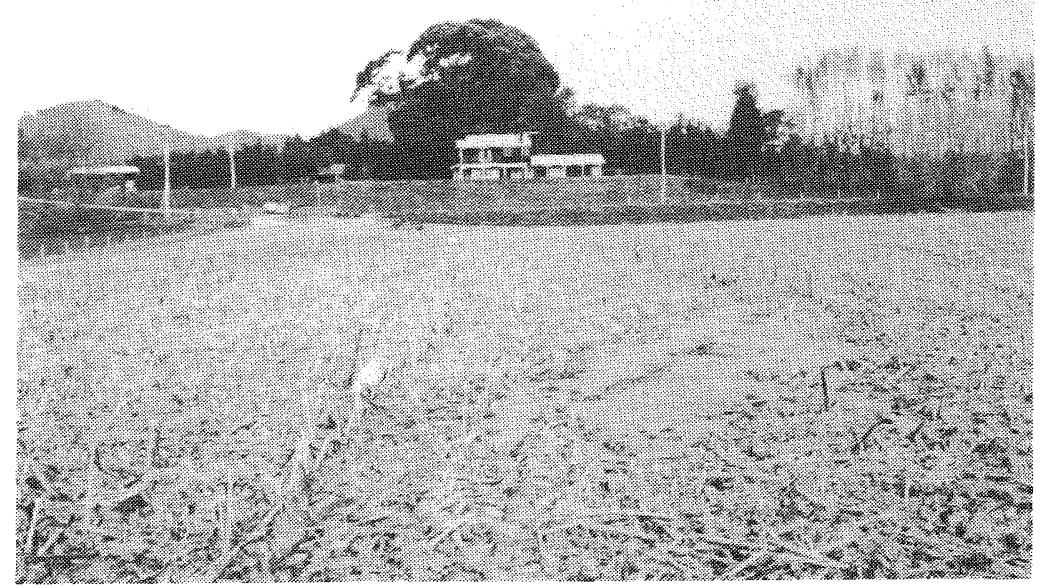

Figure 23 Looking south at a typical boil (\#40) consisting of a medium grey sand at Site 3. 


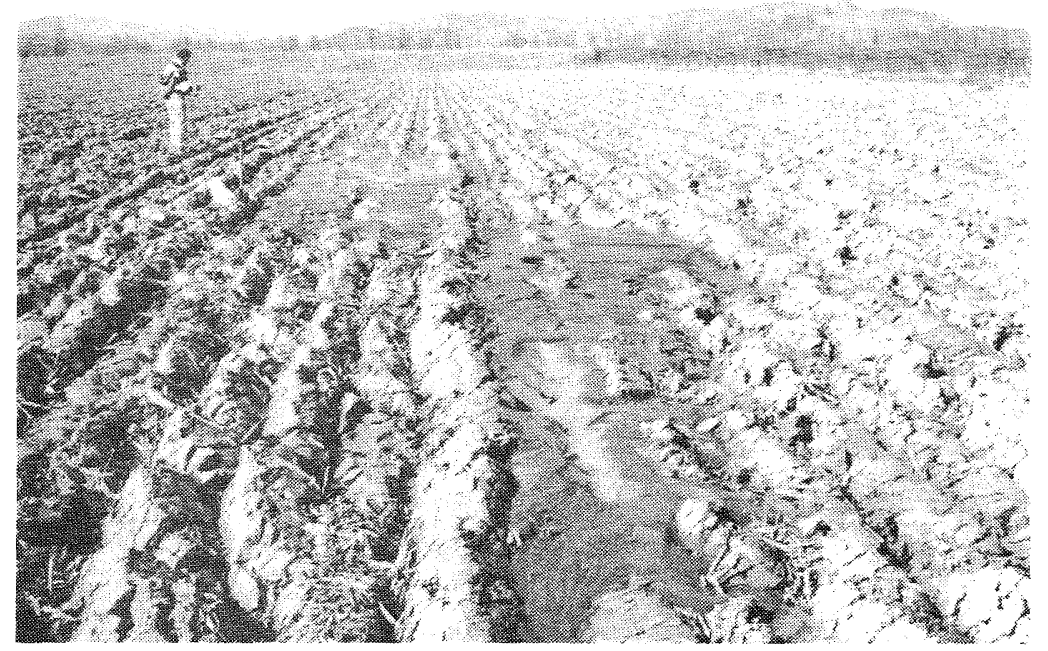

Figure 24 Boil \#90 looking east Boil is covered with medium brown sand in the foreground and fine grey sand in background

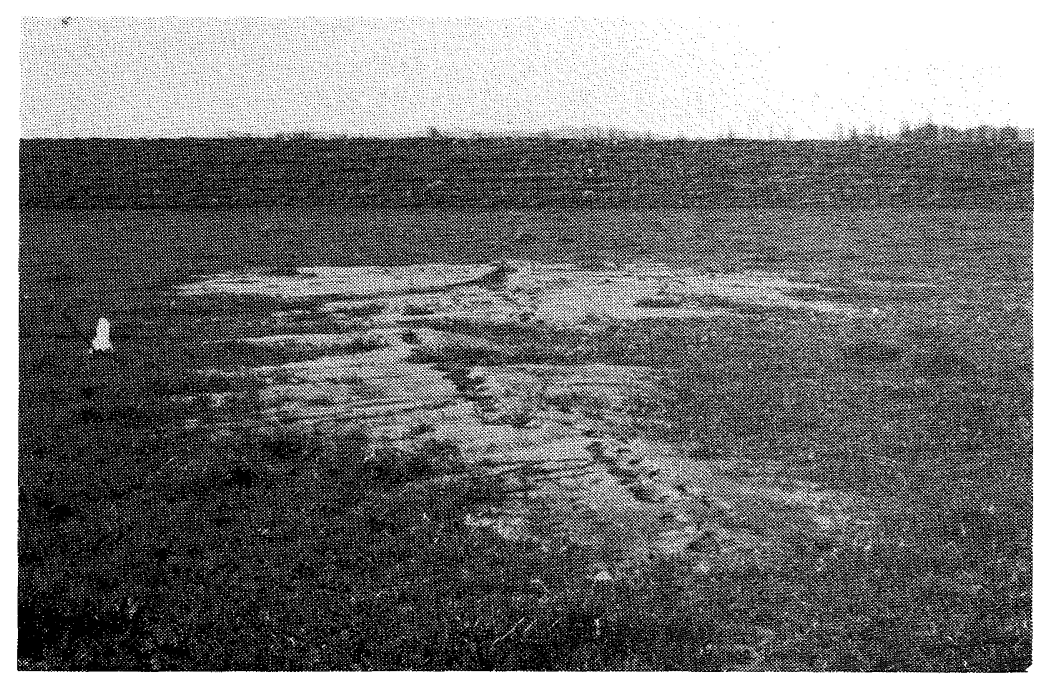

Figure 25 Closeup looking east at a typical fine grey sand boil (\#73) at Site 5.

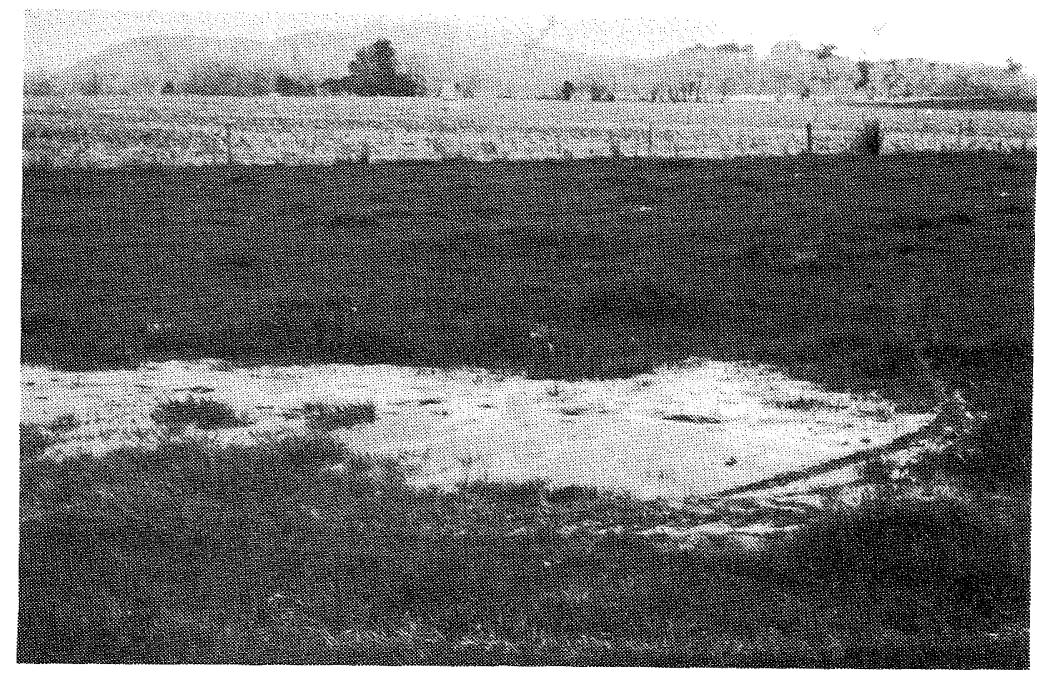

Figure 26 Closeup looking SE at a typical medium grey sand boil (\#1) at Site 1. 


\section{CONCLUSIONS}

The Ormond Earthquake should provide an interesting testing ground for liquefaction research in the future, due to the varied nature of ejected sediments produced from a earthquake with relatively low intensity.

Another interesting factor is the very deep water tables at Site 4 , and possibly other sites, indicating that the soils have been ejected from substantial depths under high confining pressures.

\section{ACKNOWLEDGEMENTS}

I would especially like to thank the Civil Engineering Department of the University of Canterbury and The Earthquake and War Damage Commission for providing funds for the reconnaissance trip.

I gratefuly acknowledge the time and contributions of $\mathrm{Mr}$ Stuart Read of the Institute of Geological and Nuclear Sciences Ltd and of Mr Greg Gummer of Royds Garden Ltd in both reconnaissance work and preparation of this report.

Special thanks to the enthusiastic farmers of the region for their interest and help.

Valuable assistance and information was also provided from the following people of whom I wish to thank:

Dr K. Cheung of Works Consultancy Services, who provided information about Site 6

the staff of Gisborne District Council,

my supervisor, Dr J. Berrill of the University of Canterbury who oversaw this work, and

$\mathrm{Mr}$ A. Roberts. of Campion College who assisted with the field work.

\section{REFERENCES}

Kuribayashi, E. and F. Tatasuoka (1975), "Brief Review of Liquefaction During Earthquakes in Japan", Soils and Foundations, Vol 15, No. 4, pp 81-92

Pullar, W.A. (1962), "Soils and Agriculture of Gisborne Plains", Soil Bureau Bulletin 20, DSIR, Wellington.

Scott, R.F. and K.A. Zuckerman (1973) "Sand Blows and Liquefaction" The Great Alaskan Earthquake of 1964. Engineering Volume, Committee on the Alaska Earthquake, Division of Earth Sciences, National Research Council, National Academy of Sciences, Washington, D.C., pp 827-845

Tsuchida, H. and S. Hayashi (1971), "Estimation of Liquefaction Potential of Sandy Soil", Proc. 3rd Meeting, U.S. Japan Panel on Wind and Seismic Effects, Tokyo.

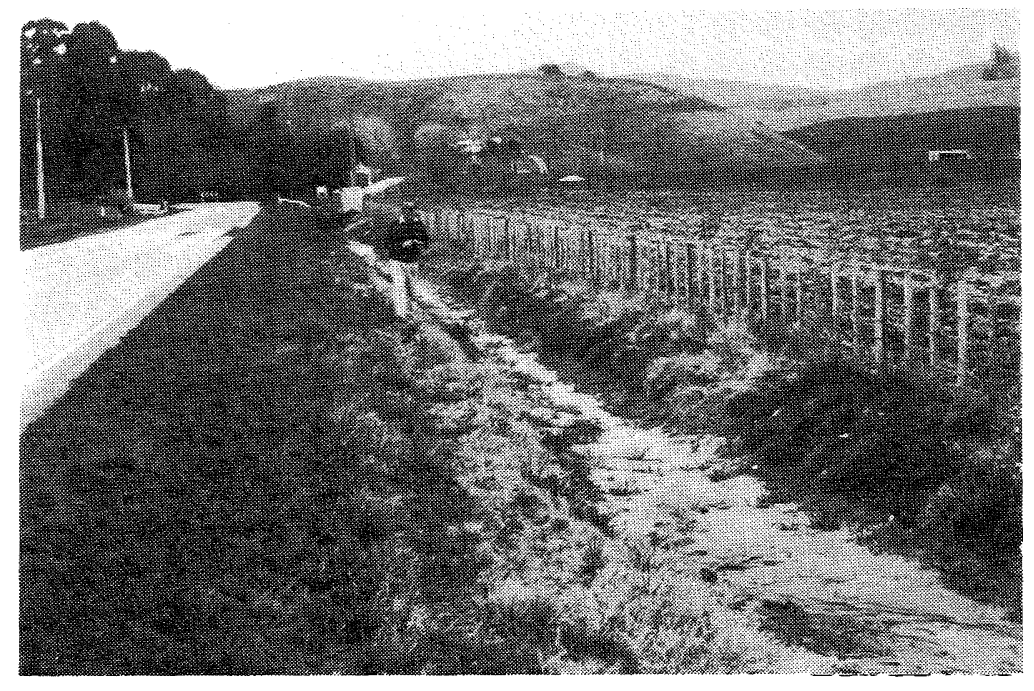

Figure 27 Boils (\#101 and \#103) in drain beside the road at Site 4. 